University of Nebraska - Lincoln

DigitalCommons@University of Nebraska - Lincoln

1997

\title{
Synthesis of a Low-Carbonate High-Charge Hydrotalcite-like Compound at Ambient Pressure and Atmosphere
}

Ravi K. Kukkadapu

Pacific Northwest National Laboratory, ravi.kukkadapu@pnl.gov

Marc S. Witkowski

Pacific Northwest National Laboratory

James E. Amonette

Pacific Northwest National Laboratory

Follow this and additional works at: https://digitalcommons.unl.edu/usdoepub

Part of the Bioresource and Agricultural Engineering Commons

Kukkadapu, Ravi K.; Witkowski, Marc S.; and Amonette, James E., "Synthesis of a Low-Carbonate HighCharge Hydrotalcite-like Compound at Ambient Pressure and Atmosphere" (1997). US Department of Energy Publications. 145.

https://digitalcommons.unl.edu/usdoepub/145

This Article is brought to you for free and open access by the U.S. Department of Energy at DigitalCommons@University of Nebraska - Lincoln. It has been accepted for inclusion in US Department of Energy Publications by an authorized administrator of DigitalCommons@University of Nebraska - Lincoln. 


\section{Synthesis of a Low-Carbonate High-Charge Hydrotalcite-like Compound at Ambient Pressure and Atmosphere}

\author{
Ravi K. Kukkadapu, Marc S. Witkowski, and \\ J ames E. Amonette*
}

Environmental and Health Sciences Division Pacific Northwest National Laboratory PO Box 999, MS K9-77

Richland, Washington 99352

Received October 14, 1996

Revised Manuscript Received December 6, 1996

Hydrotalcite (HT), a clay mineral, is constructed of brucite-like layers $\left[\mathrm{Mg}(\mathrm{OH})_{2}\right]$ in which substitution of $\mathrm{Al}^{3+}$ for $\mathrm{Mg}^{2+}$ at a mole ratio of 1:3 yields a net positive charge. This layer charge is compensated by exchangeable $\mathrm{CO}_{3}{ }^{2-}$ anions located (along with adsorbed water molecules) in the interlayer region. Numerous analogues of HT [i.e., "hydrotalcite-like" compounds (HTLCS)] have been synthesized with a variety of $\mathrm{M}^{2+} / \mathrm{M}^{3+}$ combinations, $\mathrm{M}^{2+} / \mathrm{M}^{3+}$ ratios, and interlayer anions. ${ }^{1-10}$ The compositions of these HTLCs are usually expressed using a generalized form of the formula for a substitutedbrucite, i.e., $\left[\mathrm{M}^{2+}{ }_{1-x} \mathrm{M}^{3+}{ }_{x}(\mathrm{OH})_{2}\right]^{\mathrm{x}+}\left(\mathrm{A}^{\mathrm{m}-}{ }_{\mathrm{x} / \mathrm{m}}\right) \cdot \mathrm{nH}_{2} \mathrm{O}$, where $A$ is the interlayer charge-compensating anion, and $x$ is the $\mathrm{M}^{3+} /\left(\mathrm{M}^{2+}+\mathrm{M}^{3+}\right)$ mole fraction.

Hydrotalcite and HTLCs have found use as anion exchangers, catalyst precursors, and catalyst supports. ${ }^{1}$ For applications involving catalysis or ion exchange it is desirable that the HTLCs be $\mathrm{CO}_{3}$-free and have high layer charge. The absence of $\mathrm{CO}_{3}{ }^{2-}$ is desirable because this anion is retained so strongly that access to the interlayer region by other ions and molecules is restricted and the effective anion-exchange capacity and reactive surface area are low. High layer charge (i.e., $x$ $>0.33$ ) is desirable because it increases the maximum possible exchange capacity. In addition to bulk-chemical analyses of phase-pure materials, layer charge can be estimated from the $a_{0}$ lattice parameter $\left(a_{0}=2 d_{110}\right.$ for a hexagonal unit cell) provided the ionic radii of the two cations in the hydroxide sheet (e.g., $\mathrm{Mg}^{2+}$ and $\mathrm{Al}^{3+}$ ) are sufficiently different. To our knowledge, only one report of low- $\mathrm{CO}_{3} \mathrm{HTLCs}$ having a layer charge $\geq 0.33$ has been published, ${ }^{3}$ and these samples had between 15 and $33 \%$ of the interlayer sites occupied by $\mathrm{CO}_{3}{ }^{2-}$.

In this communication, we report a new synthetic route under ambient pressure and atmosphere leading to a high-charge HTLC nearly free of inorganic C. This HTLC, which we synthesized with an $x$ value of 0.45 , consists of $\mathrm{Mg}^{2+}$ and $\mathrm{Al}^{3+}$ as the structural cations and

(1) Cavani, F.; Trifiro, F.; Vaccari, A. Catal. Today 1991, 11, 183 and references therein.

(2) Tsuji, M.; Mao, G.; Yoshida, T.; Tamaura, Y.J . Mater. Res. 1993, 8, 1137.

(3) Mao, G.; Tsuji, M.; Tamaura, Y. Clays Clay Miner. 1993, 41,

(4) Gastuche, M. C.; Brown, G., Mortland, M. M. Clay Miner. 1967, 7, 177.

(5) Miyata, S. Clays Clay Miner. 1975, 23, 369

(6) Brindley, G. W.; Kikkawa, S. Am. Mineral. 1979, 64, 836.

(7) Misra, C.; Perrota, J. Clays Clay Miner. 1992, 40, 145.

(8) Pausch, I.; Lohse, H.-H.; Schurmann, K.; Allmann, R. Clays Clay Miner. 1986, 34, 507.

(9) Thevenot, F.; Szymanski, R.; Chaumette, P. Clays Clay Miner. 1989, 37, 396.

(10) Miyata, S. Clays Clay Miner. 1983, 31, 305.

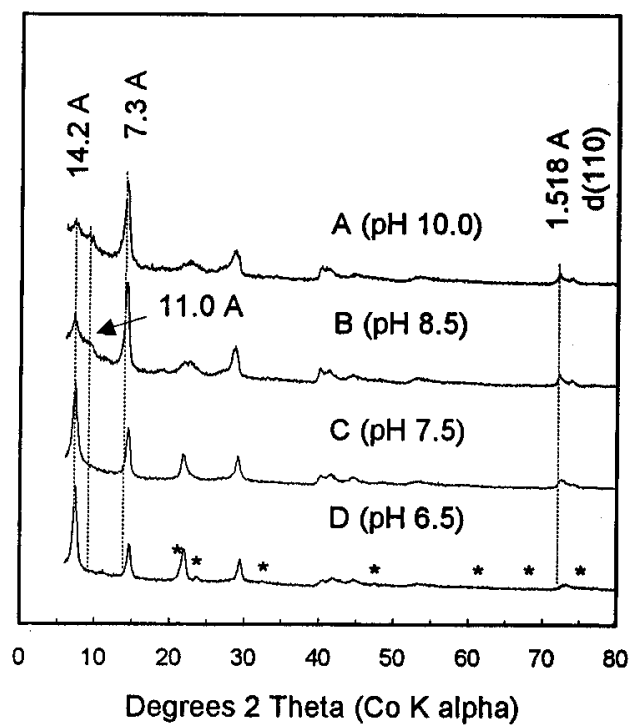

Figure 1. Powder-XRD patterns of the HTLCs obtained at $\mathrm{pH} 10,8.5,7.5$, and 6.5. Asterisk denotes major peak positions for bayerite impurity in sample D.

the terephthalate dianion $\left[\mathrm{C}_{6} \mathrm{H}_{4}\left(\mathrm{COO}^{-}\right)_{2}\right.$ or TA] as the compensating anion. Our synthesis procedure was modified from Drezdzon. ${ }^{11}$ Briefly, $5.95 \mathrm{~g}(0.035 \mathrm{~mol})$ of TA free-acid was added to a beaker containing $70 \mathrm{~mL}$ of deionized water. While stirring theTA solution, 15$17 \mathrm{~mL}(0.19-0.21 \mathrm{~mol})$ of 50 wt $\% \mathrm{NaOH}$ solution (freshly prepared and cooled to room temperature) was added dropwise to the beaker over a period of $30 \mathrm{~min}$. To this, a solution containing $17.94 \mathrm{~g}(0.07 \mathrm{~mol})$ of $\mathrm{Mg}$ $\left(\mathrm{NO}_{3}\right)_{2} \cdot 6 \mathrm{H}_{2} \mathrm{O}$ and $13.13 \mathrm{~g}(0.035 \mathrm{~mol})$ of $\mathrm{Al}\left(\mathrm{NO}_{3}\right)_{3} \cdot 9 \mathrm{H}_{2} \mathrm{O}$ in $56 \mathrm{~mL}$ of water was added dropwise while stirring the suspension vigorously at ambient temperature and pressure (the relative amounts of $\mathrm{Mg}$ and $\mathrm{Al}$ added correspond to a mole fraction, $x$, of 0.33 ). When the suspension $\mathrm{pH}$ decreased to $10,25 \mathrm{~mL}$ of the suspension was removed. Titration with the $\mathrm{Mg}$ and $\mathrm{Al}$ solution continued. Another 25- $\mathrm{mL}$ aliquot was removed when the $\mathrm{pH}$ reached 8.5 and a third aliquot was taken at $\mathrm{pH}$ 7.5. Finally, addition of $1-2 \mathrm{~mL}$ of metal nitrate solution to the remaining suspension $(\sim 65 \mathrm{~mL})$ resulted in a pH drop to about 6.5. The four suspensions were then placed in an oven and aged at $74 \pm 1^{\circ} \mathrm{C}$ overnight. After aging, the suspensions were washed by centrifugation with water until $\mathrm{NO}_{3}$-free and dried at $100{ }^{\circ} \mathrm{C}$ overnight. These oven-dried samples are referred to as samples A ( $\mathrm{pH} 10), B(\mathrm{pH} 8.5), \mathrm{C}(\mathrm{pH} 7.5)$, and $\mathrm{D}(\mathrm{pH}$ 6.5). All centrifugates (washings) were saved and analyzed for $\mathrm{Mg}$ and $\mathrm{Al}$ by inductively coupled plasma atomic-emission spectroscopy (ICP-AES). The ovendried samples were analyzed for crystalline constituents by powder XRD (smear mounts on zero-background slides, Co K $\alpha$ X-rays), for total and inorganic $C$, and for $\mathrm{Mg}$ and $\mathrm{Al}$ by ICP-AES after digestion in $\mathrm{HNO}_{3}$.

Figure 1 shows powder XRD patterns of the ovendried materials obtained at different $\mathrm{pHs}$. For sample A ( $\mathrm{pH} 10)$, the three peaks with d spacings corresponding to $14.2,11.0$, and $7.3 \AA$ reveal information about the interlayer region. The 14.2- $\AA$ peak is likely due to interlayer TA anions with the long axis perpendicular to the hydroxide layers. ${ }^{11}$ The rel atively sharp intense

(11) Drezdzon, M. A. Inorg. Chem. 1988, 27, 4628. 
Table 1. Characteristics of HTLCs Synthesized

\begin{tabular}{|c|c|c|c|c|c|c|c|}
\hline \multirow[b]{2}{*}{ sample } & \multirow[b]{2}{*}{$\mathrm{d}_{003^{\mathrm{a}}}(\AA)$} & \multirow[b]{2}{*}{$\mathrm{a}_{0} \mathrm{a}(\AA)$} & \multirow[b]{2}{*}{$x^{b}$} & \multicolumn{3}{|c|}{ anion distribution` (mol \%) } & \multirow[b]{2}{*}{ charge balance $^{d}$} \\
\hline & & & & TA & $\mathrm{CO}_{3}{ }^{2-}$ & $\mathrm{HCO}_{3}^{-}$ & \\
\hline $\mathrm{A}(\mathrm{pH} 10.0)$ & $14.2,11.0,7.3$ & 3.036 & 0.34 & 69 & 13 & 18 & 1.00 \\
\hline $\mathrm{B}(\mathrm{pH} 8.5)$ & $14.2,11.0,7.3$ & 3.038 & 0.34 & 76 & 0 & 24 & 1.02 \\
\hline $\mathrm{C}(\mathrm{pH} 7.5)$ & 14.1 & 3.024 & 0.37 & 95 & 0 & 5 & 0.96 \\
\hline \multirow[t]{2}{*}{$\mathrm{D}(\mathrm{pH} 6.5)$} & 13.9 & 3.002 & 0.45 & 98 & 0 & 2 & 1.00 \\
\hline & & & $0.47^{e}$ & & & & $0.96^{e}$ \\
\hline
\end{tabular}

a Assumes 3-layer polytype; $\mathrm{a}_{0}=2 \mathrm{~d}_{110 .}{ }^{\mathrm{b}} \mathrm{x}$ of starting solution was 0.33 . ${ }^{\mathrm{c}}$ Based on total $\mathrm{C}$ and inorganic $\mathrm{C}$ analyses; $\mathrm{CO}_{3}{ }^{2-}$ and $\mathrm{HCO}_{3}{ }^{-}$ fractions assigned to fit $x$ values. ${ }^{d}$ Sum of equivalents of $\mathrm{TA}_{1} \mathrm{CO}_{3}{ }^{2-}$, and $\mathrm{HCO}_{3}{ }^{-}$divided by charge from $\mathrm{Al}^{3+}$ substitution (all calculated on a unit-cell basis). ${ }^{e}$ Nominal values assuming no bayerite present.

peak at $7.3 \AA$ is probably a mixture of closely spaced reflections from two or three different sources. It is close to the $\mathrm{d}_{003}$ peak observed in $\mathrm{CO}_{3}-\mathrm{HTLCs}$ at 7.65 $\AA^{10}$ and thus could represent reflections from interlayers containing only $\mathrm{C}_{\text {inorg }}$ anions (i.e., $\mathrm{CO}_{3}{ }^{2-}$ and $\mathrm{HCO}_{3}{ }^{-}$). More likely it represents reflections from interlayers containing a mixture of TA anions oriented parallel to the hydroxide layers and $C_{\text {inorg }}$ anions. Last, it could contain a small contribution from the second-order reflection of the TA peak at $14.2 \AA$. The nature of the $11.0 \AA$ peak is less certain. This peak could be due to interlayer TA anions oriented at an oblique angle to the hydroxide sheet, or it could represent random interstratification of $14.2-\AA$ TA layers and $7.6-\AA \mathrm{TA} / \mathrm{C}_{\text {inorg }}$ layers.

Bulk analysis for total $\mathrm{C}$ and $\mathrm{C}_{\text {inorg }}$ was used to estimate the anionic composition of the interlayer region (Table 1). These results show that sample A contained both TA and $\mathrm{C}_{\text {inorg }}$ at a ratio of about 2:1. Analyses by Fourier transform infrared spectroscopy and ${ }^{13} \mathrm{C}$ crosspolarization magic-angle-spinning nuclear magnetic resonance spectrometry (data not shown) confirmed these results. Thus, even though no $\mathrm{C}_{\text {inorg }}$ was intentionally added to the system and excess TA was present during the precipitation process, substantial amounts of presumably atmospheric-derived $\mathrm{C}_{\text {inorg }}$ were found in the HTLC we synthesized at $\mathrm{pH} 10$.

Bulk analysis of sample $\mathrm{A}$ for $\mathrm{Mg}$ and $\mathrm{Al}$ yielded a value for $x$ nearly identical with that of the starting solution (Table 1). The sum of the charges associated with the exchangeable divalent anions (i.e., assuming only $\mathrm{CO}_{3}{ }^{2-}$ and TA) was about $10 \%$ greater than the layer charge derived from the $\mathrm{Al}^{3+}$ content. With the assumption that $\mathrm{HCO}_{3}{ }^{-}$is also present in the interlayer, a more realistic charge balance of 1.00 was obtained (Table 1). Last, the $a_{0}$ value obtained from the $d_{110}$ peak located at about $72^{\circ} 2 \theta$, which is sensitive to $x$ values, is comparable to the values reported for $\mathrm{CO}_{3}-\mathrm{HTLCS}$ with similar degrees of $\mathrm{Al}$ substitution. ${ }^{12}$ These results suggest that $\mathrm{Al}$ and $\mathrm{Mg}$ coprecipitated to yield a single phase as would be expected from the comparable solubilities of $\mathrm{Mg}(\mathrm{OH})_{2}$ and $\mathrm{Al}(\mathrm{OH})_{3}$ at $\mathrm{pH} 10 .^{13}$

Sample B ( $\mathrm{pH}$ 8.5) was similar to sample A, except for an increase in the intensity of the 14.2- $\AA$ TA peak, a corresponding decrease in the amount of $C_{\text {inorg }}$ in the interlayer, and a higher anion-charge excess (Figure 1 and Table 1). The decrease in $\mathrm{C}_{\text {inorg }}$ and the size of the ani on-charge excess suggest that all the $\mathrm{C}_{\text {inorg }}$ is $\mathrm{HCO}_{3}{ }^{-}$, which is held much less strongly than the divalent $\mathrm{CO}_{3}{ }^{2-}$ or TA anions. Such a shift to $\mathrm{HCO}_{3}{ }^{-}$would be

(12) Miyata, S. Clays Clay Miner. 1980, 28, 50

(13) Baes, C. F.J r.; Mesmer, R. E. The Hydrolysis of Cations; J ohn Wiley \& Sons: New York, 1976. driven by the decrease in solution-phase $\mathrm{CO}_{3}{ }^{2-}$ (i.e., the conversion of $\mathrm{CO}_{3}{ }^{2-}$ to $\mathrm{HCO}_{3}{ }^{-}$) as the $\mathrm{pH}$ decreases. ${ }^{14}$

Sample C (pH 7.5), on the other hand, was substantially different from samples $A$ and $B$. The XRD pattern (Figure 1 ) shows a strong TA peak at $14.1 \AA$ with three higher-order reflections. The peak at $11.0 \AA$ in patterns for samples $A$ and $B$ is absent, and that at $7.3 \AA$ has "shifted" to $7.1 \AA$, indicating that it is primarily a second-order reflection of the 14.1- $\AA$ TA peak. These results suggest that TA oriented perpendicularly to the hydroxide sheet is the dominant interlayer anion. Further evidence for this is given by the bulk carbon data (Table 1), which show that $95 \%$ of the interlayer $\mathrm{C}$ is in the form of TA and only $5 \%$ is present as $\mathrm{C}_{\text {inorg }}$ (presumably all $\mathrm{HCO}_{3}{ }^{-}$). The bulk-chemical data show an increase in the $x$ value to 0.37 and a corresponding decrease is seen in the $a_{0}$ value obtained from the $d_{110}$ peak (Table 1). Charge-balance data (i.e., TA and $\mathrm{HCO}_{3}{ }^{-}$relative to $\mathrm{x}$ ) show a slight anion "deficit", which could be due to a separate Al phase or a small quantity of $\mathrm{NO}_{3}{ }^{-}$(not determined) present in the sample (Table 1). The XRD pattern, however, suggests that the sample is phase-pure (Figure 1 ). The slight decrease in the $d$ spacing of the TA XRD peak (i.e., from 14.2 to $14.1 \AA$ ) may be a result of the higher layer charge exhibited by this sample.

Sample D (pH 6.5) continues the trends set by samples $B$ and $C$. It is essentially free of $C_{\text {inorg, }}$ has a nominal $x$ value of 0.47 and an $a_{0}$ value of $3.002 \AA$ (Table $1)$. This $a_{0}$ value is lower than the 3.016- $\AA$ value reported $^{3}$ for the $\mathrm{Mg}-\mathrm{Al}-\mathrm{Fe}(\mathrm{CN})_{6} / \mathrm{CO}_{3} \mathrm{HTLC}$ with similar $\mathrm{x}$ and suggests that the nature of the interlayer anions also contributes to the extent of lattice compression. As with sample $\mathrm{C}$, the amounts of $\mathrm{TA}$ and $\mathrm{HCO}_{3}{ }^{-}$ present correspond to $96 \%$ of the nominal layer charge, $x$, calculated from bulk-chemical analyses (Table 1). A small XRD peak at $4.36 \AA$ and the additional intensity of the peak at $4.71 \AA$ (relative to sample C), however, suggests the presence of a small amount of $\mathrm{Al}$ in a separate bayerite phase (Figure 1 ). Assuming that the true value is given by the anion charge, a value of 0.45 for $\mathrm{x}$ is obtained (Table 1). Finally, the first-order TA peak has a d spacing of $13.9 \AA$, thus continuing the trend for compression along the $c$ axis with higher layer charge. To our knowledge, sample $D$ represents the first example of an essentially $\mathrm{C}_{\text {inorg }}$-free, high-charge HTLC.

Plots of $x$ vs $a_{0}$ and $c_{0}$ (i.e., $3 d_{003}$ ) for the four HTLCs we synthesized (Figure 2) show that both cell dimensions decrease linearly with increasing $x$ and that Vegard's law is valid for these samples. The slope of

(14) Stumm, W.; Morgan, J. J . Aquatic Chemistry: Chemical Equilibria and Rates in Natural Waters, 3rd ed.; Wiley-Interscience: New York, 1996; p 149. 


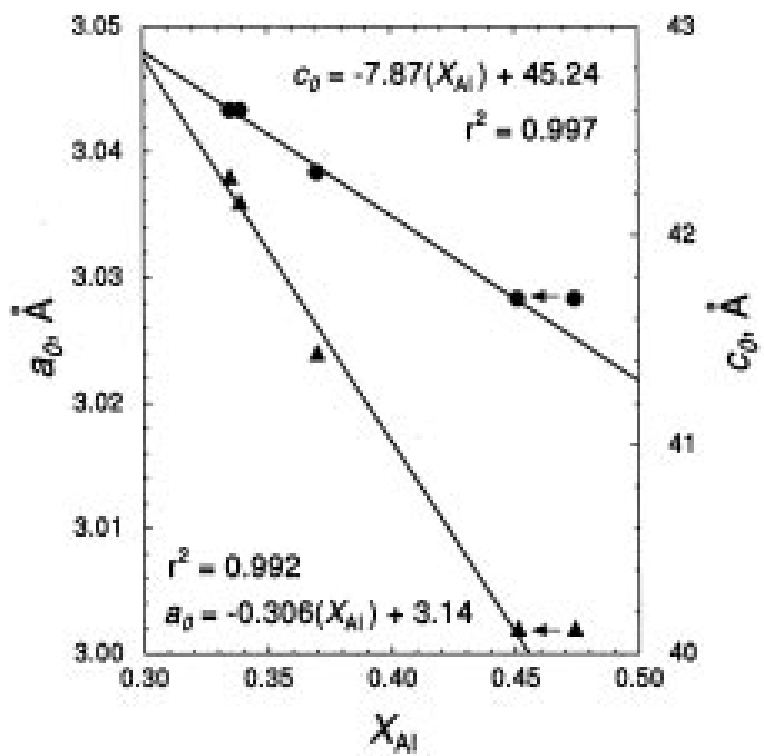

Figure 2. Relationship between $a_{0}, c_{0}$, and $x$ for the HTLCs synthesized. Values for $\mathrm{c}_{0}$ calculated using TA peaks only and assuming a three-layer polytype, i.e., $c_{0}=3 d_{003}$. Arrows denote correction of nominal $x$ values for bayerite impurity in sample D.

the $a_{0}$ plot is about $20 \%$ steeper than that reported by Miyata, ${ }^{12}$ but the $y$ intercept $(3.14 \AA)$ is closer to the theoretical value for brucite $(3.147 \AA) .{ }^{15}$ By fixing $a_{0}$ for brucite at 3.147 and incorporating the results for samples A, B, and C, Vegard's law can be used to estimate a value of $x$ for sample $D$. A value of 0.444 is obtained, which is very close to the value estimated earlier on the basis of charge balance.

Elemental analysis of the washings (data not shown) shows a net increase in $\mathrm{Mg}^{2+}$ concentration and a net decrease in $\mathrm{Al}^{3+}$ concentration in the washings from

(15) J CPDS-ICDD; Powder Diffraction File; J CPDS International Centre for Diffraction Data: Swarthmore, PA, 1986; File 7-239. sample D (pH 6.5) relative to those for sample $\mathrm{C}(\mathrm{pH}$ 7.5). These results are consonant with changes in the relative solubilities of the end-member hydroxides as $\mathrm{pH}$ decreases. As they are coupled with changes in the $a_{0}$ parameter, it seems likely that they correspond primarily to homogeneous changes in the structure of the HTLC rather than to simple dissolution of the HTLC and precipitation of an end-member $\mathrm{Al}(\mathrm{OH})_{3}$ phase. Further support for this hypothesis comes from preliminary elemental analysis data (not shown) collected by transmission electron microscopy showing that sample $\mathrm{D}$ is compositionally homogeneous on at least a $20-\AA$ scale. Similar losses of $\mathrm{Mg}^{2+}$ from $\mathrm{CO}_{3}-\mathrm{HTLCs}$ treated by acidic solutions have been noted by Kooli et al. ${ }^{16}$ and, together with our data, suggest that the composition of the hydroxide sheet is labile to some extent. The labile nature of the hydroxide sheet, however, depends on the interlayer anion. With $\mathrm{CO}_{3}{ }^{2-}$, it seems that the maximum $x$ attainable is 0.33 (data not shown), whereas, with TA, values approaching 0.5 are possible. This result adds new flexibility to our ability to synthesize HTLCs and has important implications for synthesis of other layered compounds with oxide or hydroxide structures.

Acknowledgment. Work funded by the LaboratoryDirected Research and Development program of the Pacific Northwest National Laboratory (PNNL) as part of the support for the Environmental Molecular Sciences Laboratory project. Funding for R.K.K. was facilitated by Associated Western Universities, Northwest Division. PNNL is operated for the U.S. Department of Energy by Battelle Memorial Institute under contract DE-AC06-76RLO 1830.

\section{CM960536C}

(16) Kooli, F.; Rives, V.; Ulibarri, M. A. Inorg. Chem. 1995, 34, 5122. 